\title{
Sebaran Mangrove di Desa Bumiharjo Kecamatan Keling Kabupaten Jepara
}

\author{
Suryono*, Nur Taufiq-SPJ , Ibnu Pratikto, Raden Ario \\ Departmen Ilmu kelautan, Fakultas Perikanan dan Ilmu Kelautan, Universitas Diponegoro \\ Jl. Prof. Soedarto, SH, Tembalang, Semarang, Jawa Tengah, 50275 \\ Email: suryono1960@gmail.com
}

\begin{abstract}
Abstrak
Kabupaten Jepara memiliki potensi wilayah pesisir dengan panjang garis pantai 81,6 km. Mangrove sebagai sabuk pantai hijau memiliki sebaran di setiap kecamatan pesisir. Salah satu lokasi sebaran mangrove di pesisir Jepara berada di desa Bumiharjo Kecamatan Keling. Identifikasi potensi luasan lahan serta sebaran mangrove adalah salah upaya mengetahui potensi sumberdaya pesisir. Metode penelitian yang digunakan adalah overlay peta RBI dan peta satelit landsat 8 guna mengetahui lokasi serta luasan sebaran mangrove di lokasi penelitian.Selanjutnya dilakukan investigasi ekologi mangrove dengan Survei Lapang guna mengetahui distribusi dan kelimpahan mangrove. Hasil penelitian menunjukan bahwa hutan mangrove dilokasi penelitian adalah seluas 4,75 Ha. Hasil identifikasi komposisi jenis mangrove ditemukan sebanyak 6 spesies mangrove yaitu: Avicennia marina, Rhizophora apiculata, Rhizophora stylosa, Rhizophora mucronata, Soneratia alba, serta Soneratia muconata. Kerapatan rata-rata vegetasi mangrove berkisar antara 4000-10.000 individu/ha. Tegakan mangrove memiliki tinggi batang 5-6 meter, diameter batang berkisara antara 4,3-5,0 cm. Kerapatan mangrove didominasi oleh Rhizophora mucronata. dengan kerapatan paling dominan adalah semai (Sapling). Hal ini menunjukan bahwa mangrove yang ada di desa Bumiharjo Kecamatan Keling kabupaten Jepara adalah dominan mangrove hasil replant.
\end{abstract}

Kata kunci : Identifikasi, sumberdaya, overlay, investigasi,kerapatan,replant

\section{Abstract \\ Distribution of Mangrove in The Village of Bumiharjo Keling District Jepara Regency}

Jepara Regency has a potential coastal area with a coastline length of $81.6 \mathrm{~km}$. Mangroves as coastal green belts have distribution in each coastal district. One of the mangrove distribution locations on the coast of Jepara is in the village of Bumiharjo, Keling district. Identification of the potential land area and the distribution of mangroves is an effort to determine the potential of coastal resources. The research method used is an overlay RBI map and satellite map Landsat 8 to determine the location and extent of the distribution of mangroves in research locations. Subsequently carried out an investigation of mangrove ecology with a Field Survey (Ground Truth) to determine the distribution and abundance of mangroves. The results showed that the mangrove forest in the study area was $4.75 \mathrm{Ha}$. The results of the identification of the composition of mangrove species were found as many as 6 species of mangroves, namely: Avicennia marina, Rhizophora apiculata, Rhizophora stylosa, Rhizophora mucronata, Soneratia alba, and Soneratia muconata. the average density of mangrove vegetation ranges between 4000-10,000 individuals/ha. Mangrove stand has a stem height of 5-6 meters. the diameter of the stem is between 4.3-5.0 cm. Mangrove density is dominated by Rizophora mucronata. with the most dominant density is the seedling (Sapling). This shows that the mangroves on the coast of the Jepara district are replanted mangrove species. (rehabilitation).

Keywords: Identification,resources, overlays, investigations, densities, replants

\section{PENDAHULUAN}

Kabupaten Jepara merupakan salah satu wilayah pesisir di pantai utara bagian Timur Jawa
Tengah, dengan panjang garis pantai sebesar 81,6 $\mathrm{km}$, memiliki potensi ekonomi dan sumberdaya alam yang tinggi tersimpan di sepanjang garis 
pantai tersebut, diantaranya adalah ekosistem mangrove (Bappeda Jepara, 2010). Hutan mangrove bermanfaat sebagai sumberdaya pembangunan, baik sebagai sumberdaya ekonomi maupun sumberdaya ekologi. Sumberdaya mangrove berperan sebagai habitat bagi beberapa jenis fauna, baik fauna terrestrial maupun akuatik. Ekosistem mangrove diyakini peranannya sebagai pengendali kualitas lingkungan antara daratan dan lautan (wilayah pesisir). Ekosistem mangrove juga memiliki fungsi sebagai penahan abrasi, hempasan angin, badai, tsunami, penyerap limbah dan pencegah intrusi air laut, serta sebagai tempat rekreasi (Dahuri et al. 2004). Hutan mangrove di Indonesia tersebar di beberapa wilayah, di Desa Bumiharjo Kecamatan Keling Kabupaten Jepara.

Hutan mangrove memiliki fungsi ekologis yang penting bagi sebagian besar biota akuatik (Gunarto, 2004) dan juga fungsi fisik sebagai pelindung garis pantai dan fungsi ekonomis bagi masyarakat pesisir (Jesus, 2012). Namun sayangnya sumberdaya ini dalam kondisi terancam (Valiela et al., 2001), sebagai gambaran dari 4,25 juta ha hutan mangrove yang ada di Indonesia 1,75 juta ha $(41,18 \%)$ diantaranya dalam keadaan rusak (Nontji, 2005). Permasalahan utama yang dihadapi dalam pengelolaan habitat mangrove bersumber dari berbagai tekanan yang menyebabkan luas ekosistem mangrove semakin berkurang antara lain oleh kegiatan pemukiman, tambak, ataupun berbagai kegiatan pengusahaan hutan yang tidak bertanggung jawab (Bengen, 2000). Rusaknya ekosistem mangrove telah menghilangkan fungsi fisiknya yaitu sebagai pelindung garis pantai dari gelombang laut dan angin (Karminarsih, 2007).

Kajian mengenai ekosistem mangrove di Indonesia telah banyak dilakukan oleh para peneliti diantaranya oleh Susanto et al (2013) mengamati struktur komunitas mangrove di jembatan Suramadu sisi Surabaya.Raharja et al. (2014) yang meneliti tentang potensi ekosistim mangrove di kawasan pesisir Teluk Pangang, Banyuwangi. Akbar et al. (2015) yang mengkaji ekosistim mangrove di Kawasan Pesisir Sidangoli Kabupaten Halmahera Barat. Wiyanto dan Elok (2015) menganalis vegetasi dan struktur komunitas mangrove di Teluk Benoa Bali . Agustini et al. (2016) melakukan pengamatan struktur komunitas mangrove di desa Kahyapu Pulau Enggano. Sasauw et al. (2016) yang mensurvei struktur komunitas mangrove di kelurahan Tongkaina Manado. Sunarni et al. (2019) melaporkan zonasi dan struktur komunitas mangrove di pesisir Kabupaten Merauke.
Penelitian tentang ekosistim mangrove di Jawa tengah telah dilakukan pada beberapa lokasi, antara lain oleh Suryono (2015) meneliti ekologi mangrove di Segara Anakan Jawa Tengah. Prasetya et al. (2016) yang meneliti struktur konmunitas mangrove di kepulauan Karimunjawa Kabupaten Jepara Mauludin et al. (2018) meneliti komposisi dan tutupan kanopi Mangrove di Ujung Piring, Kabupaten Jepara.

Salah satu daerah yang memiliki potensi hutan mangrove di Kabupaten Jepara adalah di desa Bumiharjo kecamatan Keling, namun kondisinya belum banyak diketahui. Oleh karena itu maka perlu dilakukan identifikasi sebaran mangrove yang ada guna perencanaan rehabilitasi kawasan kritis pesisir melalui penanaman mangrove dalam pengelolaan sumberdaya pesisir dan lautan yang berkelanjutan.

\section{MATERI DAN METODE}

Metode penelitian yang digunakan dalam penelitian ini adalah dengan overlay peta RBI dan peta satelit landsat 8 guna mengetahui lokasi serta luasan sebaran mangrove di lokasi penelitian. Selanjutnya dari hasil peta sebaran mangrove dilakukan investigasi ekologi mangrove dengan.Survei Lapang (Ground Thruth) guna mengetahui distribusi dan kelimpahan mangrove. Pengambilan sampel dilakukan dengan metode purposive sampling sedangkan metode penentuan lokasi transek dilakukan secara acak terstratifikasi (stratified random sampling) (Nazir, 2005), Penelitian ini dilakukan dengan menggunakan metode yang merupakan modifikasi dari cara yang digunakan oleh Mueller Dumbois dan Ellenberg (1974). Pada tiap stasiun ditetapkan minimal 3 titik pengambilan sampel yang diharapkan dapat mewakili lokasi tersebut. Selanjutnya pada masing-masing stasiun diambil data pohon (tree) pada transek berukuran $10 \mathrm{~m} \mathrm{x}$ $10 \mathrm{~m}$ (dbh $\geq 10 \mathrm{~cm})$. Sedangkan untuk data anakan (sapling) $(2 \mathrm{~cm} \leq \mathrm{dbh}<10 \mathrm{~cm})$ diambil dalam transek berukuran $5 \mathrm{~m}$ x $5 \mathrm{~m}$ dan semai (seedling) dengan ketinggian $<2 \mathrm{~m}$ diambil dalam transek $1 \mathrm{~m}$ x $1 \mathrm{~m}$.

Individu mangrove yang ditemukan dalam plot diidentifikasi menurut nomenklatur Primavera dan Sadaba (2012), Primavera et al. (2014), Feller dan Sitnik (1996), dan Tomlinson (1986). Prosedur pengamatan yang dilakukan untuk masing-masing kategori adalah sebagai berikut : Pohon ; data pohon $(\mathrm{dbh} \geq 4 \mathrm{~cm})$ diambil dari masing-masing plot $10 \mathrm{~m} \times 10 \mathrm{~m}$ berupa spesies. Pengukuran diameter, sedikit dilakukan modifikasi yang direkomendasi oleh Cintron dan 


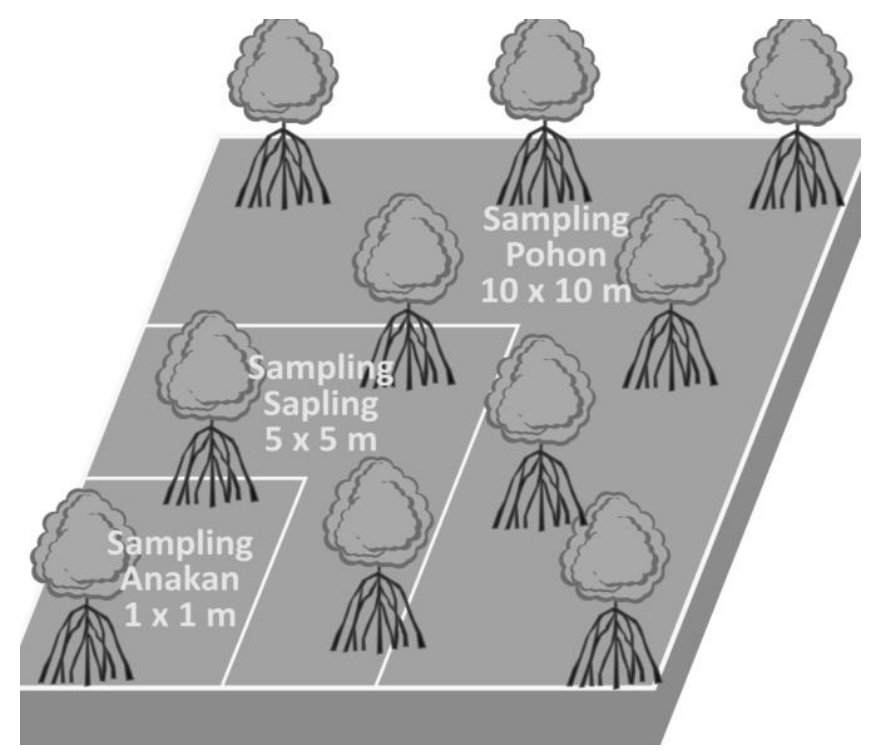

Gambar 1. Cara peletakan plot. Keterangan : $10 \mathrm{~m}$ x 10m untuk kategori pohon; $5 \mathrm{~m} \times 5 \mathrm{~m}$ untuk kategori anakan atau sapling; dan $1 \mathrm{~m}$ x $1 \mathrm{~m}$ untuk kategori semai atau seedling (Pribadi, 1998,dan Kemen LH, 2004).

Novelli (1984) Sapling : berupa vegetasi mangrove yang memiliki diameter batang $1 \leq \mathrm{dbh}$ $<4$ dan tingginya > $1 \mathrm{~m}$. Seedling: berupa vegetasi mangrove dengan ketinggian $<1 \mathrm{~m}$ pada subplot $1 \mathrm{~m} \times 1 \mathrm{~m}$. Pada setiap plot diidentifikasi jenis tumbuhan mangrove yang ditemukan secara menyeluruh, mengukur lingkaran tiap batang mangrove yang ditemukan, kemudian mencatat jumlah individu masing-masing spesies mangrove tersebut (Cintron dan Novelli, 1984; Noor et al., 2006). Selanjutnya dilakukan analisis untuk mengetahui nilai kerapatan, kerapatan relatif, basal area, dominansi, dominansi relatif dan nilai penting (Cintron dan Novelli, 1984). indek keanekaragaman Shannon Weiner, indek keseragaman Evernness dan indek kesamaan Sorenson vegetasi mangrove mengacu pada Odum (1993).

\section{HASIL DAN PEMBAHASAN}

Luasan hutan mangrove di dukuh Bringin Desa Bumiharjo, Kecamatan Keling, Kabupaten Jepara adalah seluas 4,75 $\mathrm{Ha}$ ha. Hasil Survei Lapang (Ground Thruth) hutan mangrove berada pada tanah milik kawasan Cagar Alam Keling, BKSDA Pati Barat, PTP VI, serta Pemerintah Desa Bumiharjo (Gambar 2).

Hasil identifikasi komposisi jenis mangrove ditemukan sebanyak 6 spesies mangrove yaitu: Avicennia marina, Rhizophora apiculata, Rhizophora stylosa, Rhizophora mucronata, Soneratia alba serta Soneratia muconata. Hasil identifikasi spesies pada setiap plot pengamatan baik pada sapling, sedling, maupun pohon hanya ditemukan satu spesies mangrove yaitu Rhizophora mucronata. Kerapatan mangrove ratarata vegetasi mangrove berkisar antara 4000 10.000 individu/ha. Tegakan mangrove memiliki tinggi batang 5-6 meter. diameter batang berkisar antara 4,3-5,0 cm. Data Hasil identifikasi distribusi mangrove kategori pohon, sapling dan seedling disajikan pada Tabel 1 dan Gambar 3 .

Hasil penelitian menunjukkan bahwa jumlah vegetasi mangrove yang ditemukan, yaitu 6 jenis mangrove adalah lebih rendah apabila dibandingkan dengan yang ditemukan di beberapa lokasi. Seperti misal Agustini et al. (2016), melaporkan ada 8 (delapan) spesies mangrove sejati dan 8 (delapan) spesies mangrove asosiasi di desa Kahyapu Pulau Enggano, di kawasan Pesisir Barat dan Timur Nangroe Aceh Darussalam (NAD) ditemukan mangrove yang mencapai 25 jenis (Cahyo, 2006),di Karimunjawa ditemukan 7 jenis mangrove (Prasetya et al., 2016), Sunarni et al. (2019) mendapatkan 15 jenis mangrove di pesisir Kabupaten Merauke Papua . Suryono (2015) menemukan 10 jenis mangrove didapatkan dari Segara Anakan Cilacap Jawa Tengah, Susanto et al (2013) mengatakan bahwa ditemukan tujuh spesies dan empat famili yang menyusun vegetasi mangrove di sekitar Jembatan Suramadu sisi Surabaya, Wiyanto dan elok (2015) melaporkan vegetasi mangrove yang ditemukan 11 spesies mangrove sejati dan 1 jenis 


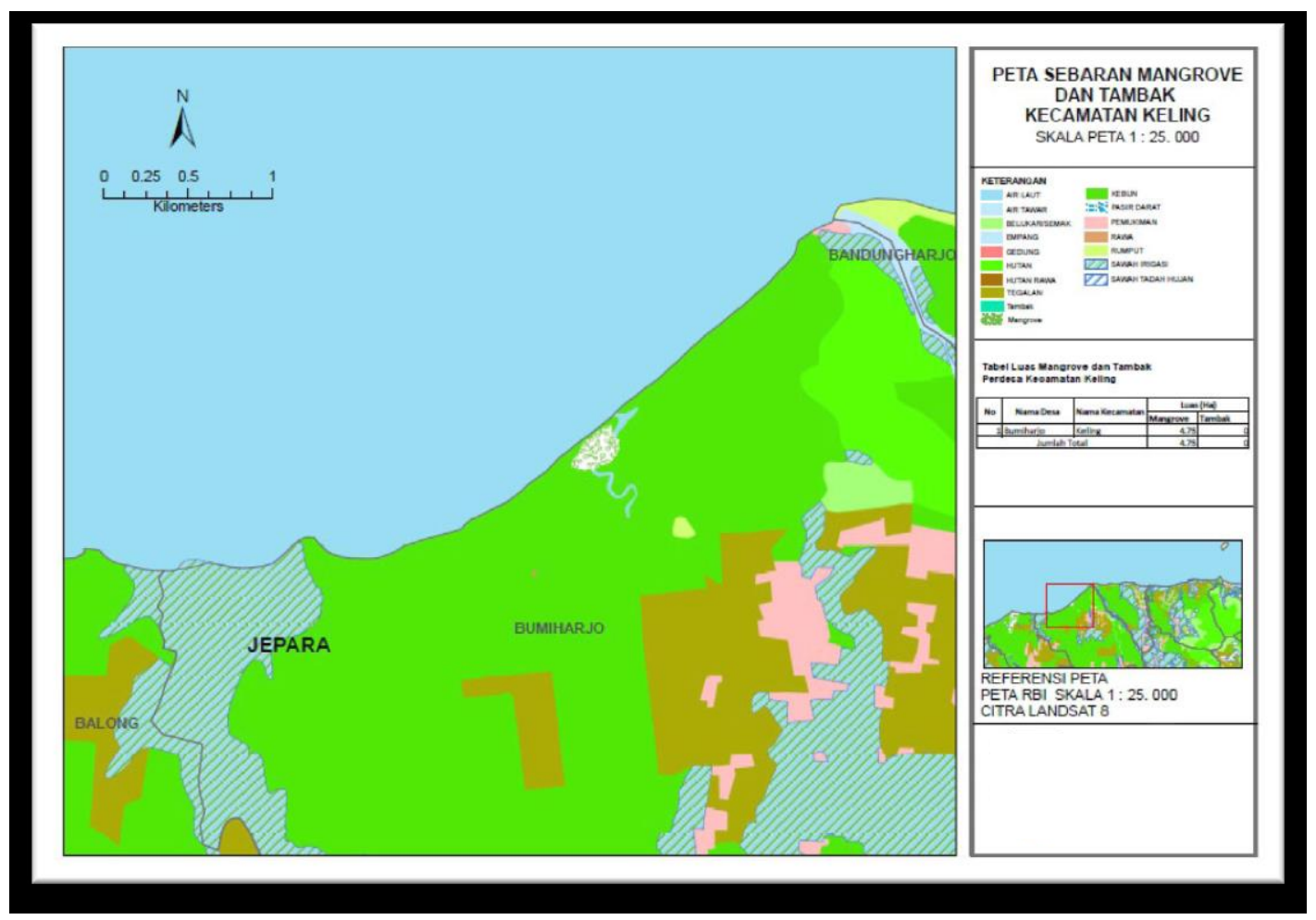

Gambar 2. Peta Sebaran Mangrove di desa Bumiharjo Kecamatan Keling, Kabupaten Jepara

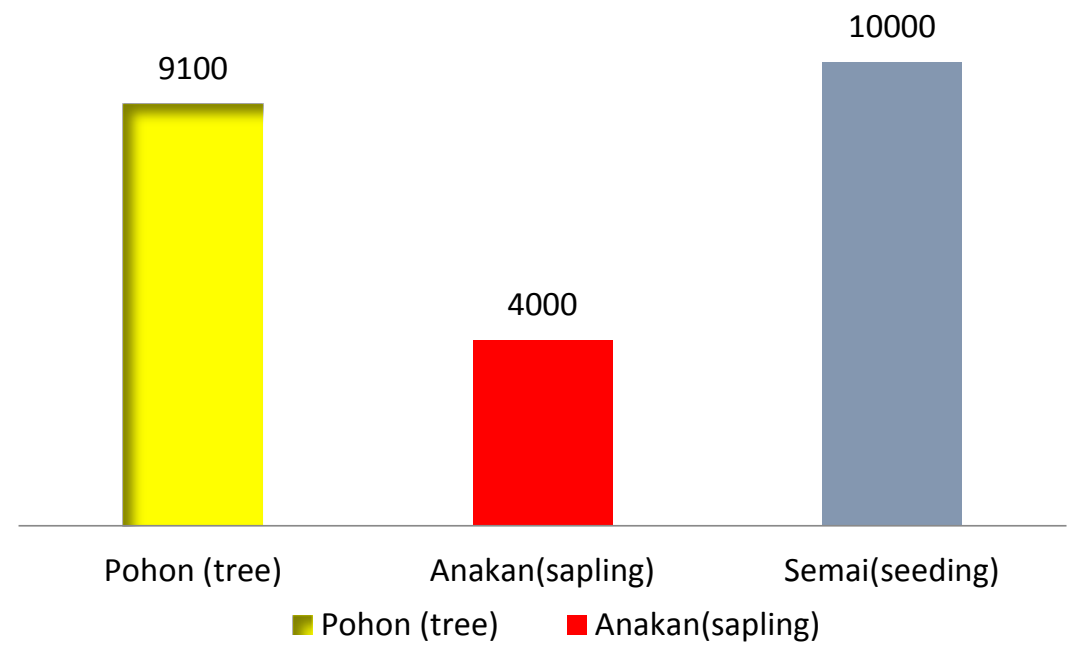

Gambar 3. Kerapatan pohon (tree), anakan (sapling),dan semai (seedling) mangrove Rhizophora mucronata desa Bumiharjo Kecamatan Keling Kabupaten Jepara

Tabel 1. Distribusi Mangrove Rizophora mucronata berdasarkan ni (jumlah total tegakan jenis ke-i ) Kerapatan (Ind/ha), Keanekaragaman (H'), Keseragaman (J'), Dominasi (D), Basal Area (BA), dan Nilai Penting (NP) di desa Bumiharjo Kecamatan Keling.Kabupaten Jepara.

\begin{tabular}{ccccccccc}
\hline $\begin{array}{c}\text { Jenis } \\
\text { Mangove }\end{array}$ & Katagori & ni & K & H' & $\mathrm{J}^{\prime}$ & $\mathrm{D}$ & $\begin{array}{c}\mathrm{BA} \\
\left(\mathrm{cm}^{2}\right)\end{array}$ & $\mathrm{NP}$ \\
\hline \multirow{2}{*}{$\begin{array}{c}\text { Rhizophora } \\
\text { mucronata }\end{array}$} & Pohon & 91 & 9100 & 0 & 0 & 100 & 2790.08 & 200 \\
& Sapling & 10 & 4000 & 0 & 0 & 100 & 100.95 & 200 \\
& Seedling & 1 & 10000 & 0 & 0 & 100 & 5 & 200 \\
\hline
\end{tabular}


mangrove ikutan di Teluk Benoa Bali. Hal ini dikarenakan hutan mangrove yang diteliti adalah merupakan hutan mangrove yang masih terbentuk secara alami. Disamping itu diduga dikarenakan perbedaan tekanan ekologis yang antara ekosistem mangrove di Papua, Nangroe Aceh Darusalam (NAD) , Bali, Pulau Enggano, Segara nanakan Cilacap, dan sekitar Jembatan Surama dibandingkan dengan ekositem mangrove di pesisir Kabupaten Jepara. Hasil penelitian mengkonfirmasi seperti yang terjadi pada sebagian besar wilayah pesisir di Pulau Jawa, bahwa tingginya jumlah penduduk yang tinggal di lokasi penelitian menjadi faktor tekanan ekologis terhadap mangrove (Dahuri et al., 2004).

Dari hasil penelitian dapat diketahui bahwa ekosistem mangrove dominansi oleh spesies Rhizophora mucronata, famili Rhizophoraceae, yang merupakan spesies yang dapat beradaptasi dengan baik pada kondisi tanah yang berlumpur. Kondisi tanah seperti ini sesuai dengan lokasi penelitian dengan substrat tanah yang berlumpur. Hal ini sesuai dengan yang dikemukakan oleh Chapman (1976), dan Nugroho et al. (1991) bahwa sebagian besar spesies-spesies mangrove dapat tumbuh dengan baik pada tanah berlumpur, terutama di daerah dimana endapan lumpur tersebut terakumulasi. Adanya kondisi lingkungan yang berlumpur dan berpasir merupakan substrat yang cocok untuk pertumbuhan dan perkembangan mangrove dari famili Rhizohoraceae. Selain itu, dominasi jenis spesies ini sesuai dengan apa yang dikemukakan oleh Arif, (2003), bahwa Kelompok yang dominan pada suatu ekosistem mangrove adalah jenis mangrove dari famili Rhizophoraceae. Selain kondisi substrat yang sesuai, dominasi spesies Rhizophora mucronata juga didukung oleh faktor lingkungan yang cocok yakni dengan suhu lingkungan berkisar antara $25^{\circ} \mathrm{C}$ sampai $29^{\circ} \mathrm{C}$ merupakan suhu yang cocok untuk pertumbuhan mangrove.

Rusila-Noor et al. (1999) menyatakan terdapat penyesuaian antara vegetasi dengan sedimen dasarnya di suatu lokasi. Rhizophora mucronata dapat tumbuh baik mengingat di lokasi dengan substrat sedimen berupa lumpur bercampur pasir yang kaya akan humus serta memiliki aerasi yang baik dan sebagian besar lokasi pendataan digolongkan sebagai habitat tumbuh dan hidup yang ideal karena letaknya di teluk, sehingga terlindung dari aksi gelombang.
Menurut Arief (2003), tipe tanah merupakan salah satu faktor penunjang terjadinya proses regenerasi, dimana partikel debu dan partikel liat yang berupa lumpur mampu menangkap buah dari. Selanjutnya dikatakan bahwa Rhizophora mucronata memiliki perakaran yang sangat kuat sehingga dapat bertahan dari hempasan ombak, yang merupakan zona perintis atau pionir, dan menyukai tanah berlumpur lembek dan mampu hidup pada tanah yang berkadar garam tinggi.

Kerapatan jenis tumbuhan mangrove yang diteliti terdiri dari beberapa tingkatan yaitu tingkatan pohon, anakan dan semai. Kerapatan tertinggi ditemukan pada tingkat semai (seedling) yaitu 10.000 individu/Ha, kemudian secara berurutan pad tingkat pohon sejumlah 9.100 individu/Ha dan 4000 individu/Ha. Benih ini ketika masih pada tumbuhan induk, berkecambah dan mulai tumbuh didalam semaian tanpa mengalami istirahat. Hal ini merupakan salah satu faktor tingginya nilai kerapatan jenis pada semai Rhizopora mucronata. nilai kerapatan jenis pada tingkat pohon sedikit lebih jarang jika dibandingkan dengan semai. Salah satu faktor yang mempengaruhi rendahnya nilai kerapatan jenis tingkat pohon adalah besarnya nilai penutupan mangrove dengan diameter berkisar antara 4,3-5 cm, kondisi ini kurang memungkinkan untuk pertumbuhan pohon mangrove dalam kondisi rapat. Faktor lain yang menyebabkan pertumbuhan mangrove relatif kurang adalah kondisi akar pohon yang tergolong besar sehingga pertumbuhan mangrove tersebut menjadi kurang optimal (Agustini et al, 2016.) Tingginya nilai kerapatan jenis ini juga dipengaruhi oleh nilai penutupan jenis anakan yang masih relatif kecil dengan diameter $<10 \mathrm{~cm}$. Faktor ini yang mendukung pertumbuhan jenis mangrove secara lebih optimal. Menurut Kepmen LH No. 201 Tahun 2004, kriteria nilai kerapatan jenis mangrove pada nilai $\geq 1500$ maka tergolong kategori sangat rapat dan pada nilai < 1000 maka tergolong dalam kategori jarang.

Nilai Indeks Keanekaragaman (H') pada lokasi penelitian sangat rendah, dimana nilai Indeks Keanekaragaman (H') yaitu 0. Indeks Keseragaman ( $\left.\mathrm{J}^{\prime}\right)$ di lokasi penelitian tergolong rendah, dimana Indeks Keseragaman (J') adalah 0 . Rendahnya nilai Indeks Keanekaragaman $\left(\mathrm{H}^{\prime}\right)$ dan Indeks Keseragaman (J') di lokasi penelitian adalah 0 , dikarenakan jumlah individu tiap spesies (Ni) pada setiap plot transek hanya ditemukan 1 
spesies yaitu Rhizophora mucronata. Nilai indeks keanekaragaman (H') dan Indeks Keseragaman (J') yang didapatkan tergolong rendah. Hal ini menunjukkan bahwa komunitas mangrove di desa Bumiharjo Kecamatan Keling kabupaten Jepara memiliki kompleksitas rendah karena tidak terjadi interaksi spesies di dalam komunitas hutan mangrove yang ada. Menurut Indriyanto (2006) keanekaragaman spesies juga dapat digunakan untuk mengukur stabilitas komunitas, yaitu kemampuan suatu komunitas untuk menjaga dirinya tetap stabil. Indeks Nilai Penting (INP) mangrove yang didapatkan terdiri dari beberapa tingkatan yaitu tingkatan pohon, anakan dan semai, yang mempunyai nilai sama yaitu 200 . Indeks nilai penting (INP) mangrove menunjukkan keterwakilan jenis mangrove yang berperan dalam ekosistem dengan kisaran nilai antara 0-300. Menurut Romadhon (2008), apabila INP berkisar antara 106-204 maka tergolong sedang. Keanekaragaman spesies mangrove yang rendah dikarenakan ekosistem mangrove yang ada merupakan ekosistem buatan (Tefarani et al, 2019), dari upaya rehabilitasi / mangrove replant yang dilakukan (Chrisyariati dan Hendrarto, 2014). Informasi dari narasumber lokal (NSL) yaitu para pemangku kepentingan Kepala desa/Petinggi desa Bumiharjo, OISCA-JICA area Jepara, organisasi perangkat daerah (OPD) Kabupaten Jepara mengkonfirmasi bahwa telah dilakukan mangrove replant di lokasi penelitiaan sejak tahun 2005.

Hasil penelitian mengkonfirmasi bahwa ekositem buatan hutan mangrove hasil rehabilitasi/mangrove replant replant di desa Bumiharjo kecamatan Keling Kabupaten Jepara perlu ditindak lanjuti dengan strategi pengelolaan ekosistem mangrove dengan memaksimalkan fungsi ekosistem mangrove . Diperlukan rumusan naskaah akademik rencana pengelolaan ekosistem mangrove yang melibatkan para pihak pemangku kepentingan. Distribusi mangrove di desa Bumiharjo Kecamatn Keling Kabupaten Jepara berada pada tanah milik kawasan Cagar Alam Keling, BKSDA Pati Barat, PTP VI, serta Pemerintah Desa Bumiharjo. Mengingat pentingnya fungsi dan peranan dari ekosistem mangrove, maka perlu adanya penguatan pemahaman semua pihak untuk menjaga keberlangsungan ekosistem mangrove. Diperlukan penguatan penegakan peraturan tentang pemanfaatan dan pengelolaan mangrove yang dikelola secara terpadu oleh berbagai pihak untuk menghindari konflik dan terjadinya sinergitas para pihak .

\section{KESIMPULAN}

Hasil penelitian menunjukkan bahwa jumlah vegetasi mangrove yang ditemukan, yaitu 6 jenis mangrove. Indeks Keanekaragaman $\left(\mathrm{H}^{\prime}\right)$ dan Indeks Keseragaman (J') di lokasi penelitian mempunyai nilai rendah,sedangkan Indeks Nilai Penting (INP) mangrove yang didapatkan tergolong sedang. Hal ini disebabkan adanya dominansi spesies tertentu yang sangat tinggi yaitu spesies Rizophora mucronata. Kerapatan mangrove paling dominan adalah semai (seedling). Hal ini menunjukan bahwa sebaran mangrove yang ada di desa Bumiharjo Kecamatan Keling Kabupaten Jepara adalah dominan hasil replant (rehabilitasi).

\section{DAFTAR PUSTAKA}

Agustini, N.T., Ta'alidin, Z. \& Purnama, D., 2016. Struktur Komunitas Mangrove Di Desa Kahyapu Pulau Enggano. Jurnal Enggano, 1(1):19-31.

Akbar, N., Baksir, A. \& Tahir, I.. 2015. Struktur komunitas ekosistem mangrove di kawasan pesisir Sidangoli Kabupaten Halmahera Barat. Maluku Utara. Depik, 4(3):132-143.

Arief, A.2003. Hutan Mangrove: Fungsi Dan Manfaatnya, Penerbit Kanius. Yogyakarta

Bappeda Kabupaten Jepara .2010 RIPDA Kabupaten Jepara

Bengen, G.D. 2000. Penentuan dan Pengelolaan Kawasan Lindung di Pesisir, Laut dan PulauPulau Kecil. Bahan Seminar oleh Departemen Kelautan dan Perikanan, Jakarta.

Cahyo, W. 2006. Penilaian Data Lingkungan Pasca Tsunami. Wetlands International. Jakarta.

Chapman, V.J. 1976. Mangrove Vegetation. J. Cramer, Vadus, Liechtensein, Germany.

Cintron, G \& Novelli, Y.C., 1984. Methods for studying mangrove structure in Snedakar, S. $\mathrm{C}$ and Snedaker, C. G. The Mangrove ecosystem research method. UNESCO. United Kingdom. pp: $91-113$.

Chrisyariati, I., \& Hendrarto, B. 2014. Kandungan nitrogen total dan fosfat sedimen mangrove pada umur yang berbeda di lingkungan pertambakan Mangunharjo, Semarang. Management of Aquatic Resources Journal, 3(3):65-72. 
Dahuri, R., Rais, J., Ginting, S.P. \& Sitepu, M.J. 2004. Pengelolaan Sumberdaya Wilayah Pesisir dan Lautan Secara Terpadu. PT.Pradnya Paramita.Jakarta

Feller, I.C., \& Sitnik, M., 1996. Mangrove Ecology: A Manual for a Field Course. Smithsonian Institution, Washington, DC, USA.

Gunarto. 2004. Konservasi mangrove sebagai pendukung sumber hayati perikanan pantai. Jurnal Litbang Pertanian, 23(1):15-21.

Indriyanto. 2006. Ekologi Hutan. PT. Bumi Aksara, Jakarta.

Jesus, A.D. 2012 Kondisi ekosistim mangrove di sub district Liquisa Timor-Leste. Depik, 1(3): 136-143.

Karminarsih, E. 2007. Pemanfaatan ekosistem mangrove bagi meminimalisasi dampak bencana di wilayah pesisir. Jurnal Manajemen Hutan Tropika, 13:182-187.

KepMen LH. 2004. Kriteria Baku Dan Pedoman Penentuan Kerusakan Mangrove. Keputusan Menteri Negara Lingkungan Hidup, Nomor 201.

Mauludin, M.R., Azizah, R., Pribadi, R. \& Suryono, S., 2018. Komposisi dan Tutupan Kanopi Mangrove di Kawasan Ujung Piring Kabupaten Jepara. Buletin Oseanografi Marina, 7(1):29-36.

Mueller-Dombois, D. \& Ellenberg, H. 1974. Aims and Methodes of Vegetation Ecology. John Wiley, London.

Nazir, M. 2005. Metode Penelitian. Penerbit Ghalia, Bogor.

Nontji. 2005. Laut nusantara. Djambatan, Jakarta.

Noor, Y.R., Khazali, M. \& Suryadiputra, I.N.N. 2006. Panduan pengenalan mangrove di Indonesia. Direktorat Jenderal Perlindungan Hutan dan Konservasi Alam dan Wetlands Indonesia, Bogor.

Nugroho, S.G., Setiawan, A., \& Harianto, S.P. 1991. "Coupled Ecosystem Silvofishery" Bentuk Pengelolaan Hutan MangroveTambak yang Saling Mendukung dan Melindungi. Prosiding Seminar IV Ekosistem Mangrove Panitia Nasional Program MAB Indonesia-LIPI. Jakarta

Odum, E.P. 1993. Dasar dasar ekologi. Gajah Mada University Press. Yogyakarta. 693 hal.

Prasetya, J.D., Ambariyanto, Supriharyono, \& Purwanti, F. 2016. Mangrove Health Index as part of Sustaible Managemen In Mangrove ecosystem at Karimunjawa National Marine
Park Indonesia. American Scientific Plublisers., v (n):p1-p2.

Pribadi, R. 1998. The Ecology of Mangrove Vegetation in Bintuny Bay, Irian Jaya Indonesia. Departement of Biological Molecular Sciences. University of Stirling, Scotlandia. (Ph.D. Thesis Unpublished).

Primavera, J.H. \& Sadaba, R.B., 2012. Beach Forest Species and Mangrove Associates in the Philippines. Southeast Asian Fisheries Development Centre (SEAFDEC), Philippines.

Primavera, J.H., Sadaba, R.B., Lebata, M.J.H. \& Altamirano, J.P. 2004. Handbook of Mangroves in the Philippines: Panay. Southeast Asian Fisheries Development Centre (SEAFDEC), Philippines.

Raharja, A.B., Widigdo, B., \& Sutrisno, D. 2014. Kajian potensi kawasan mangrove di kawasan pesisir Teluk Pangpang, Banyuwangi. Depik, 3(1):36-45.

Romadhon. 2008. Kajian Ekologi Melalui Inventarisasi dan Nilai Indeks Penting (INP) Mangrove Terhadap Perlindungan Lingkungan Kepulauan Kangean. Embryo,.5 (1):82-97

Rusila-Noor, Y., Khazali, M. \& Suryadiputra, I.N.N. 1999. Panduan Pengenalan Mangrove di Indonesia. PHKA/WI-IP, Bogor.

Sasauw, J., Kusen, J. \& Schaduw, J., 2017. Struktur Komunitas Mangroce di Kelurahan Tongkaina Manado. Jurnal Pesisir dan Laut Tropis, 4(2):.17-22.

Sunarni, S., Maturbongs, M.R., Arifin, T. and Rahmania, R. 2019. Zonasi dan Struktur Komunitas Mangrove Di Pesisir Kabupaten Merauke. Jurnal Kelautan Nasional, 14(3):165-178.

Suryono, A.C. 2015. Ekologi Mangrove di Segara Anakan Ditinjau Dari Aspek kelimpahan dan Distribusi. Jurnal Kelautan Tropis, 18(1):2027

Susanto, A.H., Soedarti, T. \& Purnobasuki, H., 2013. Struktur Komunitas Mangrove Di Sekitar Jembatan Suramadu Sisi Surabaya. 10(1):1-10

Tefarani, R., Martuti, N.K.T. \& Ngabekti, S., 2019. Keanekaragaman spesies mangrove dan zonasi di wilayah Kelurahan Mangunharjo Kecamatan Tugu Kota Semarang. Life Science, 8(1):41-53.

Tomlinson, P.B..1986. The Botany of Mangroves. New York: Cambridge University Press. 
Valiela, I., Bowen, J.L., York, J.K. 2001. Mangrove forest: One of the world's threatened major tropical environments. Bioscience, 51(10):807-815.
Wiyanto D.B. \& Faiqoh, E. 2015. Analisis vegetasi dan struktur komunitas Mangrove Di Teluk Benoa, Bali. Journal of Marine and Aquatic Sciences 1:1-7. 